Article

\title{
How Do Investment Banks Price Initial Public Offerings? An Empirical Analysis of Emerging Market
}

\author{
Abdul Rasheed * (D), Muhammad Khalid Sohail, Shahab-Ud Din and Muhammad Ijaz \\ Department of Management Sciences, COMSATS University Islamabad, 45550 Islamabad, Pakistan; \\ Khalid_sohail@comsats.edu.pk (M.K.S.); shahab_53129@hotmail.com (S.-U.D.); \\ muhammadijaz@comsats.edu.pk (M.I.) \\ * Correspondence: rasheed_online@hotmail.com; Tel.: +92-321-4674326
}

Received: 24 May 2018; Accepted: 18 July 2018; Published: 5 September 2018

\begin{abstract}
This study investigates that how investment banks select alternative valuation models to price Initial Public Offerings (IPOs) and examine the value-relevance of each valuation model using the data of 88 IPOs listed on the Pakistan Stock Exchange (PSX) during 2000-2016. This study investigates that investment banks used Dividend Discount Model (DDM), Discounted Cash Flow (DCF) and comparable multiples valuation models on the basis of firm-specific characteristics, aggregate stock market returns and volatility before the IPOs. In this study, a binary logit regression model is used to estimate the cross-sectional determinants of the choice of valuation models by investment banks. The results reveal that underwriters are more likely to use DDM to value firms that have dividends payout trail. The investment banks select DCF when valuing the younger firms, that have more assets-in-tangible, firms that have negative sales growth and positive market returns before the IPO; while comparable multiples are used for mature firms and firms that have less assets-in-tangible. Furthermore, this study also used OLS regressions to examine the value-relevance of each valuation model and Wald-test to examine the predictive power of cross-sectional variation in the market values. The findings unveil that $\mathrm{P} / \mathrm{B}$ ratio has highest but DCF has lowest predictive power to market values. The Wald-test results depict that none of the valuation methods produces an unbiased estimate of market values.
\end{abstract}

Keywords: valuation models; Initial Public Offerings; Pakistan Stock Exchange

JEL Classification: G00; G24; G30

\section{Introduction}

Thousands of public limited companies around the globe have offered their shares to the general public through the primary markets in the last couple of decades. An Initial Public Offerings (IPO) is a procedure whereby a firm sells its shares first time to the general public through fixed price or bookbuilding auction. A decision to raise equity capital through selling stock to general public is a significant event in the lifecycle of issuer firm. Chang et al. (2013) argue that most firms decide to go public in hot-issue ${ }^{1}$ market due to the several IPO stylized facts such as leave less money ${ }^{2}$ on the

1 A situation when the number of new offerings gets listed with great pace than the usual number of new offerings in a certain time period.

2 Leave less money on the table means underwriters deliberately set offer price discount at the time of going public to compensate the market liquidity risk for more details see Ritter $(1984,1988)$ and Ritter and Welch $(2002)$. 
table, favorable investor sentiments ${ }^{3}$, over-valued stock prices and to avoid time-varying adverse selection problem.

In the most recent, the majority of Pakistani IPOs are priced using the book building method (Rasheed and Sohail 2019). Under the book building process, the lead underwriters decide final offer/strike price in two steps. First, they estimate a preliminary offer price range mainly using the dividend discount model, discounted cash flow method and/or the comparable multiples methods. Second, then the institutional investors determine strike price on the basis of their own interest, valuation estimates and inside information (Paleari and Vismara 2007; Sherman and Titman 2002). Roosenboom (2012) argues that it is difficult to access actual IPO valuation process employed by investment banks to price IPOs because in many countries it is not mandatory to disclose the underwriter's valuation forecast in the prospectus. Bradley et al. (2003) document that the US underwriters are not allowed to publish valuation predictions about IPO firms. In Pakistan, pre-IPO valuation estimates by investment banks are often disclosed in the prospectus documents. As per the Securities and Exchange Commission of Pakistan (SECP) directives, the prospectus documents need to comply with international standards and a section about firm's valuation and justifications of price premium should be included. The availability of valuation disclosure in Pakistan allows investors to analyze how IPOs are priced and how this valuation affects the pricing of IPOs. Abdulai (2015), Roosenboom (2012) and Deloof et al. (2009) document that lead underwriters deliberately discount the offer prices to attract more participation in the bidding process. Their findings reveal that the prestigious underwriters' offered less offer price discounts while less reputed underwriters' offer large price discounts.

Although, the most existing literature on IPOs mainly paying attention to aftermarket performance with limited concentration to the ex ante valuation and pricing of those IPOs (Deloof et al. 2009). Cassia et al. (2004) and Roosenboom (2007) first time highlight this limited concentration in developed markets, while Hearn (2011) highlights in emerging market, on IPO valuations that how underwriters value ex ante valuations and set final offer price. Pereiro (2006) argues that accumulative stance of this lack of attention in emerging markets is the difficulty of implanting the common valuation models that are usually preserve of valuing IPOs in the developed markets because emerging markets are relatively small in size and highly concentrated nature.

Apparently, it has been observed that the discussion regarding selecting comparable firms for valuation is very little in the emerging economies. As a result, the practitioners usually employ explanation of comparable firms based on developed economies when valuing IPOs using multiples in the circumstance of emerging economies (Goh et al. 2015; Ivashkovskaya and Kuznetsov 2007). Schreiner and Spremann (2007) conjectured that the criterion to select comparable firms is complicated to be recognizing because each firm confronts different business issues. Damodaran (2005) argues that the practitioners are unable to implement multiples correctly because they mainly depend on subjective decisions. Roosenboom (2007) was emphatic about this lack of attention when noticing that the IPO literature, particularly on valuation, is not very thick. In the emerging market of Africa, Hearn (2011) mentions the lack of attention about IPOs' valuation and predicted accuracy of several valuation methods in literature. Pereiro (2006) compounded the problems of less attention to IPO valuations and pricing studies in the emerging markets, investment banks usually applying traditional methods used for valuation in the developed economies. Nwude (2010) argues that the appropriate methods for Nigerian IPOs' valuation and pricing are problematic because of an extant literature unable to provide clear-cut valuation methods. The extant literature inspected this issue for developed and developing countries but the country like Pakistan has not taken into account and this study is devoted to analyzing the numerous aspects of valuation practices when pricing Pakistani IPOs.

3 When investors are least concerned about market risk, valuation and willing to pay high prices based on good current and forecasted macroeconomic factors. 
The findings of this study contribute to the knowledge of to what extent the Pakistani capital market has converged on the way to or diverged from a mature market.

The key objectives of this study are to examine that how investment banks select valuation models when pricing IPOs and value-relevance of each valuation model to predict market value estimates. This study contributes and explains to the IPO valuation practice in Pakistan using the underwriters' valuation analysis information published in the prospectus. It has been observed that the Pakistani underwriters frequently used dividend discount model, discounted cash flow and comparable multiples valuation approaches to estimate the fair value estimates on the basis of firm-specific characteristics, aggregate stock market returns and aggregate stock market volatility before the IPOs.

This study makes two significant contributions to the literature. First, this study enlightens the valuation practice and use of different valuation methods when pricing IPOs in Pakistan. Due to limited financial statements trail, the different firm-specific characteristics, aggregate stock market returns and aggregate stock market volatility at the time of pricing IPOs may impact the selection of alternative valuation models. This study examines the impact of preceding factors on the selection of different valuation models. It has been observed that the multiples method is a widely accepted valuation method in Pakistan, contrary to previous studies, which document that investment banks mostly focus on discounted cash flow models and tend to ignore the multiples method (e.g., Abdulai 2015; Deloof et al. 2002, 2009; Demirakos et al. 2004; Cassia et al. 2004), maybe, because of a time-specific effect: most issuing firms went public during the hot-issue market phase, a period of bullish market phases when the selection of multiples might have led to overvaluation.

Second, this study employs 'real-world' estimations disclosed in the prospectus to investigate the value relevance of valuation models when pricing IPOs, in contrast to Colaco et al. (2013, 2017), Yoon (2015), Chang and Tang (2007), Purnanandam and Swaminathan (2004) and Kim and Ritter (1999), who used ex post price estimates. Few studies investigate the accuracy of earnings forecasts when valuing IPOs instead of focusing on value relevancy (e.g., Herawati et al. 2017; Campbell et al. 2008; How et al. 2007; Jog and McConomy 2003; Gonoupolis 2003; Chen and Firth 1999), while DeAngelo (1990) use 'real-world' estimations for management buyouts but do not discuss the value relevancy.

The rest of the study is ordered as follows. Section 2 briefly talks about the relevant literature of choice and value relevancy of valuation models. Section 3 describes the sample and methodology used in this study. Section 4 presents the results and discussion and Section 5 concludes the summary and future directions of study.

\section{Literature Review}

The valuation regarding IPOs has devoted limited attention in the existing literature. Based on the valuation theory, each model should turn out the same valuations if they are properly constructed. On the other hand, the relative dominance of each valuation model in academic research and in practice is an unsettled issue.

In the literature of post-issue financial data based valuation studies conclude that the most of authors completely rely on comparable multiples, on the basis of similar industry, size, revenue growth and earnings, valuation methods to estimate a fair value of issuing firm's equity while very few studies, only compare the valuation estimates using DCF and comparable multiples method. Boatsman and Baskin (1981), Alford (1992), Chang and Tang (2007) argue that P/E selected on the basis of industry membership produce more valuation accuracy than selected on the basis of other benchmarks, while (Purnanandam and Swaminathan 2004; Chang and Tang 2007; Campbell et al. 2008; Colaco et al. 2013) P/E selected on the basis of forward earnings produce higher valuation accuracy than the price/EBITDA and price/sales multiples. Kaplan and Ruback (1995), Gilson et al. (2000) and Berkman et al. (2000) found a similar valuation accuracy for DCF and comparable multiples. 
Bhojraj and Lee (2002) conclude that the peers selected on the basis of predicted EV/Sales and Price/book ratios produce more prudent estimates than peers selected based on other techniques.

Penman (2007) and Koller et al. (2000) argue that the multi-period valuation models based on DCF and residual income methods produce more accurate valuation estimates than the single-period multiples valuation method. Even though, an extant literature depicts the selection of valuation models by financial analysts and professional investors stand contrasts to the theoretical superiority of multi-period direct valuation methods. Bradshaw (2002) argues that the NPV is rarely used in the equity valuation. Barker (1999a) explains that the predicted future cashflows and suitable discount rate may make a multi-period DCF become too difficult. Demirakos et al. (2004) draw attention that the residual income model and option pricing models are rarely used in equity valuations. They also mentioned that comparable multiples are most common for stable sectors, while (Barker 1999b) finds that the $\mathrm{P} / \mathrm{E}$ ratio is the foremost valuation measure in the consumer goods and services sectors, while DDM is more important for utilities and financial sectors. Glaum and Friedrich (2006) conduct a survey of equity analysts of telecom firms and find that both DCF and multiples are the preferred valuation methods; however, the DCF is the dominant valuation model over the multiples. The findings of IPO literature that used underwriter's 'real-world' valuation analysis information to estimate a fair value and accuracy of several valuation methods employed when valuing IPOs demonstrate that investment banks employed DDM, DCF, P/E, P/B and economic value-added method to estimate fair value estimates. Deloof et al. (2009) find the similar valuation accuracy of DDM and DCF while Berkman et al. (2000) and Deloof et al. (2002) find that the DCF valuation method produces more valuation accuracy than $\mathrm{P} / \mathrm{E}, \mathrm{P} / \mathrm{B}$ and other multiples to estimate fair value estimates. In contrast, Cassia et al. (2004), Schreiner and Spremann (2007), Demirakos et al. (2010), Roosenboom (2012) and, Goh et al. (2015) argue that the comparable multiples such as P/E and P/B valuation multiples outperform the DDM and DCF in order to produce more accurate fair value estimates. The literature on valuation biases also depicts that the $\mathrm{P} / \mathrm{E}$ ratio produces less valuation bias than other methods (Deloof et al. 2002; Cassia et al. 2004; How et al. 2007), while Deloof et al. (2009) document that the DCF produce less valuation bias than DDM and on the similar pattern, Francis et al. (2000) report DDM produce less valuation bias than the DCF.

Finally, the empirical evidence concludes that the majority valuation studies mainly draw attention to compare the valuation accuracy of alternative valuation models and to select comparable firms for multiples method. A limited attention is drawn regarding what decides the selection of valuation models. Demirakos et al. (2004) argue that multiples method is more appropriate to value beverage industry because it differentiates by stable growth than electronics and pharmaceutical industries. Roosenboom (2007) investigates that how French underwriters choose the valuation method to set preliminary IPO offer prices using the sample of 228 French non-financial firms from 1990 to 1999. He used pre-IPO characteristics, valuation methods disclosed in offering documents, and the unique data of detailed valuation reports from the leading financial advisors. This study points out that underwriters have a preference to choose peer group multiples valuation when valuing rapidly growing, technology and profitable firms. They prefer to use dividend discount model when valuing older firms from the mature industries because older firms pay major portion of their earnings as dividends and when the aggregate stock market returns are low before going public. The discounted free cash flow model and the economic-value added valuation measures used when aggregate stock market returns are high prior to IPO. Deloof et al. (2009) investigate that how do underwriters value the IPOs using numerous valuation methods of 49 non-financial IPO firms listed on the Euronext Brussels from 1993 to 2001. They observed that the discounted free cash flow, the dividend discount and the peer group multiples valuation approaches used by Belgium investment banks, of which DFCF is noticed to value in all the IPOs, the offer prices are value relevant to DDM estimations when DDM is used and the peer group multiples valuation based on the forecasted earnings and cash flows produce more accurate estimates than based on the latest financial earnings and the cash flows disclosed in the offering documents. Abdulai (2015) investigates the impact of choice, pricing 
and performance of different valuation measures on the aftermarket performance of 30 IPOs listed on the Ghana Stock Exchange during 1992-2012. The findings reveal that the operating profitability before the IPO is a significant determinant of choice of multiples while firm age, size and dividend payout are the key determinants of discounted cash flow model. Goh et al. (2015) investigate the choice of different multiples of newly-listed firms related agricultural business sector listed in Malaysia during 2003-2009. They employ Price-earnings (P/E), Price-book (P/B), Price-cash flow (P/CF), Price-sales $(\mathrm{P} / \mathrm{S})$, price-total assets $(\mathrm{P} / \mathrm{TA})$ and Return-on-equity (ROE) ratios for comparable firms based on the industry membership and the firm's rate of growth. The findings reveal that; (1) the median is an accurate measure to estimate the comparable multiples and the accuracy of valuation measures; (2) the ROE used as a control factor adjustment in the comparable firms leads to unbiased valuation estimates; (3) the price-sales $(\mathrm{P} / \mathrm{S})$ ratio perform worst in the valuation performance while price-earnings ratio produce more accurate valuations when valuing the agribusiness IPOs.

\section{Methodology}

\subsection{Data and Sample}

This study starts with the complete universe of all newly-listed firms by either offer for sale and/or new placements on the Pakistan Stock Exchange previously known as Karachi Stock Exchange during 2000-2016. A total of 126 firms went public on PSX during the sample period. As similar to an extant literature, this study excludes 38 firms from the population as: excluded 16 firms that went public without publishing prospectus documents to general public because these firms were listed on PSX due to Specie Dividend announced by their parent firms to their existing shareholders, merger and demerger events, excluded 16 firms listed as closed-end mutual funds because their reporting environments are not comparable with the other sectors IPO firms and six prospectus documents are missing in the data. These sample selection criteria result as a sample of $88(70 \%)$ Pakistani firms who went public during the sample period. Therefore, a sample of 88 firms stretches across the years and a catalog of selection criteria are presented in Table 1.

Table 1. Sample Selection Criteria and Description.

\begin{tabular}{|c|c|c|c|c|c|c|}
\hline \multirow{2}{*}{ Sr. No. } & \multirow{2}{*}{ Year } & \multirow{2}{*}{$\begin{array}{l}\text { Total Listed } \\
\text { Firms }\end{array}$} & \multicolumn{3}{|c|}{ Restrictions } & \multirow{2}{*}{ Sample IPO Firms } \\
\hline & & & Without IPO Listings & Mutual Funds & Missing IPOs & \\
\hline 1 & 2000 & 3 & 0 & 0 & 0 & 3 \\
\hline 2 & 2001 & 3 & 0 & 0 & 1 & 2 \\
\hline 3 & 2002 & 4 & 0 & 0 & 0 & 4 \\
\hline 4 & 2003 & 6 & 2 & 0 & 1 & 3 \\
\hline 5 & 2004 & 17 & 1 & 6 & 2 & 8 \\
\hline 6 & 2005 & 19 & 1 & 4 & 0 & 14 \\
\hline 7 & 2006 & 10 & 3 & 4 & 1 & 2 \\
\hline 8 & 2007 & 15 & 2 & 2 & 1 & 10 \\
\hline 9 & 2008 & 10 & 1 & 0 & 0 & 9 \\
\hline 10 & 2009 & 4 & 1 & 0 & 0 & 3 \\
\hline 11 & 2010 & 6 & 0 & 0 & 0 & 6 \\
\hline 12 & 2011 & 4 & 0 & 0 & 0 & 4 \\
\hline 13 & 2012 & 4 & 1 & 0 & 0 & 3 \\
\hline 14 & 2013 & 3 & 2 & 0 & 0 & 1 \\
\hline 15 & 2014 & 6 & 1 & 0 & 0 & 5 \\
\hline 16 & 2015 & 8 & 1 & 0 & 0 & 7 \\
\hline 17 & 2016 & 4 & 0 & 0 & 0 & 4 \\
\hline \multicolumn{2}{|c|}{ Total Firms } & 126 & 16 & 16 & 6 & 88 \\
\hline
\end{tabular}

This study used secondary data for the choice of valuation models and value-relevancy analysis. The data used in the choice and accuracy of underwriter's valuation approaches is hand collected from the prospectus documents that published at the time of formal listing on the PSX. The IPO share price data is collected from the official websites of PSX and business recorder. 


\subsection{Research Methodology}

\subsubsection{Enlightening the Choice of Valuation Methods Model}

We construct an econometric methodology to enlighten the choice for a particular valuation model employed by underwriters in the domain of new offerings. This study employs the binary logit regression model comparable with Roosenboom $(2007,2012)$ and Deloof et al. $(2009)$ to examine the cross-sectional determinants of the selection of valuation methods used by underwriters. The binary logit model is used, due to binary outcomes of each valuation method variable (dummy variable), to predict the probabilities of binary outcome of given predictor variables. This study estimates the following models.

$$
\begin{gathered}
{[\text { Multi, DCF, DDM }]} \\
=\beta_{0}+\beta_{1} \text { LnSize }_{i}+\beta_{2} \text { Ln }\left(1+\text { age }_{i}+\beta_{3} \text { AIP }_{i}+\beta_{4} \text { PROF }_{i}\right. \\
+\beta_{5} \text { GROW }_{i}+\beta_{6} \text { DIV }_{i}+\beta_{7} \text { Tech }_{i}+\beta_{8} \text { MktRet }_{i}+\beta_{9} \text { SD }_{i}+\beta_{10} \text { URep }_{i} \\
+\beta_{11} \text { DilutionFactr }_{i}+\varepsilon_{i}
\end{gathered}
$$

In the Equation (1), the dependent variable is a dummy variable that equals one if the underwriter uses peer group multiples valuation model for IPOs' valuation and zero otherwise. On the similar pattern, if the underwriter uses the discounted cash flow model then the dependent variable equals one and zero otherwise and so on. The peer group multiples valuation method is used for comparative valuation while DCF and DDM valuation models are direct valuation techniques. The operational definitions of variables used in the model are presented in Table 2.

We also test the equality of coefficients from different valuation models using the Z-test. The Z-test equation is provided by Clogg et al. (1995). Where $\beta_{1}$ and $\beta_{2}$ are the coefficients from two different valuation models and $S E_{\beta 1}$ and $S E_{\beta 2}$ are the standard errors of $\beta_{1}$ and $\beta_{2}$ respectively.

$$
Z=\frac{\beta_{1}-\beta_{2}}{\sqrt{\left(S E_{\beta 1}\right)^{2}+\left(S E_{\beta 2}\right)^{2}}}
$$

The firm size is estimated using the natural logarithm of total assets as Log(Total Assets) from the latest financial year statements disclosed in the prospectus prior to IPO. This study employed natural logarithm of total assets to normalize the distribution of data and to control the 'scale effect' issue. Ritter (1984) and Beatty and Ritter (1986) argue that the larger IPO firms can be easily estimated as they are more stable in terms of market share, revenue growth, payout history and forecasted cash flows. This helps to employ direct valuation models such as discounted cash flow model and dividend discount model more probably. The firm age is estimated using natural logarithm of one plus firm age as $\log (1+$ Age $)$ is considered as an ex-ante uncertainty. Ritter (1984) argues that the degree of uncertainty inversely associated with the age of a firm. Kim and Ritter (1999) point out that it is difficult to predict future cash flows and payouts for younger firms without creating financial statements track record because many of their estimations based on the expectations regarding future growth rates, which significantly differ from firm to firm case. Therefore, the older firms are valued by direct valuation models more likely. We estimate assets tangibility (AIP) as the ratio of property, plant and equipment to total assets of the latest preceding year as disclosed in the prospectus. Lev (2001) argues that the accounting numbers supposed to be a good estimator of the firm value of their tangible assets than intangible assets. Therefore, the firms with high assets tangibility increased the use of accounting-based valuation methods, such as the economic value-added method. This study theorizes that the underwriters probably to employ peer group multiples to value IPO firms when they predict that the issuer firm is comparatively profitable (PROF) in the year of issue. If the underwriters are predicting that the issuing firm expected to be marginally profitable or documenting loss on the basis of a due diligence report, the IPO valuation estimates and management prospects about future cash 
flows, they prefer to use other valuation methods than multiples valuation because applying the $\mathrm{P} / \mathrm{E}$ ratio in these situations results negative or low multiples valuation.

Table 2. Operational definitions of variables used in the binary logitmodel.

\begin{tabular}{|c|c|}
\hline Variable & Definition \\
\hline \multicolumn{2}{|c|}{ Dependent Variable } \\
\hline Multiples & $\begin{array}{l}\text { Dummy variable equals one if underwriter uses the peer group multiples valuation } \\
\text { method and zero otherwise. }\end{array}$ \\
\hline DCF & $\begin{array}{l}\text { Dummy variable equals one if underwriter uses the discounted cash flow valuation } \\
\text { method and zero otherwise. }\end{array}$ \\
\hline DDM & $\begin{array}{l}\text { Dummy variable equals one if underwriter uses the dividend discount model and } \\
\text { zero otherwise. }\end{array}$ \\
\hline \multicolumn{2}{|c|}{ Independent Variables } \\
\hline LnSize & The natural logarithm of total assets for the latest financial year disclosed in the prospectus. \\
\hline Ln(1+Age) & $\begin{array}{l}\text { The natural logarithm of one plus firm age (a difference between the IPO listing year } \\
\text { minus the date of incorporation) }\end{array}$ \\
\hline AIP & $\begin{array}{l}\text { The Ratio of property, plant and equipment to total assets for the latest financial year } \\
\text { disclosed in the prospectus }\end{array}$ \\
\hline GROW & Forecasted Sales growth during the current year \\
\hline Div & $\begin{array}{l}\text { Dummy variable equals one if the IPO firm has a track record of payout history and/or } \\
\text { disclosed dividend policy in the prospectus prior to an IPO and zero otherwise }\end{array}$ \\
\hline Tech & $\begin{array}{l}\text { Dummy variable equals one if the IPO firm belongs to a technology industry and } \\
\text { zero otherwise }\end{array}$ \\
\hline MktRet & $\begin{array}{l}\text { The aggregate market returns during a } 180 \text { days interval from } 185 \text { th trading day before to } \\
\text { 5th trading day before the formal listing date of IPO firm. (KSE100 index has been used for } \\
\text { market returns) }\end{array}$ \\
\hline SD & $\begin{array}{l}\text { The standard deviation of daily market returns during a } 180 \text { days interval from the 185th } \\
\text { trading day before to 5th trading day before the formal listing date of IPO firm. }\end{array}$ \\
\hline URep & $\begin{array}{l}\text { A dummy variable for underwriter's reputation, takes the value of } 1 \text { for prestigious } \\
\text { underwriters and } 0 \text { for less reputed underwriters }\end{array}$ \\
\hline Prof & The ratio of current year forecasted EBIT to current year forecasted sales \\
\hline Dilution Factor & The ratio of newly issued shares over Total post-issue outstanding shares \\
\hline
\end{tabular}

In this study, predicted sales growth in the IPO year is used as a proxy for growth opportunities. The rapidly growing firms face challenges of cash imbalances in the short to medium term because their capital investments are more than the cash inflows. Penman (2001) argues that the discounted cash flow model treats capital investments as a loss of value and free cash flow model unable to recognize the value that does not engage cash flows. In addition, the rapidly growing firms tend to retain their earnings as capital reserves than the offer them out as cash dividends. The rapidly growing firms are valued by multiples valuation method because of persistent investment in growth opportunities. Therefore, we hypothesize that the rapidly growing firms are more likely to be valued using the multiples valuation than direct valuation methods. One of the most important features of our data is that Pakistani IPO firms typically report their historical payouts (DIV) and/or payout pattern of their associated companies in prospectus documents. Firms that have a track record to announce high dividends perceived as quality firms. Bhattacharya (1979) argues that the high-quality firms only announce dividends to their shareholders to signal their quality. In his theoretical explanations, dividends tend to be a non-recoverable expense and visible signal to stakeholders while low-quality firms prefer to use internal financing instead of expensive outside financing. A trend of consistent payout (DIV) in the preceding years compels underwriters to value IPO firms using the dividend discount model. Damodaran (1994) points out that the dividend discount model is a best measure for 
valuing stable and high dividend paying firms. Therefore, it is hypothesized that the underwriters are more likely to use dividend discount model during setting the fair value estimates for IPO firms that pay a large portion of their earnings as dividends in the past.

Bartov et al. (2002) argue that technology-based companies are more difficult to assess in terms of their fair value estimates because a major division of their fair value comes from their growth opportunities. Therefore, it is anticipated that the technology firms are probably to be assessed using the multiples valuation method than direct estimation methods such as discounted cash flow model and dividend discount model because these models do not incorporate the value of growth options in the fair value estimates. A dummy variable is used to control the impact of technology companies (Tech) that equals one if the IPO firm is high-tech firm and zero otherwise. Discounted cash flow estimates are sensitive to forecasted cash flows and discount rates as estimated by underwriters to value IPOs. DeAngelo (1990) points out that it is not very convincing to external shareholders due to the sensitivity of value estimates set by underwriters, investors are more likely to go for those IPOs in which window of opportunity prevails. A persistent rise in aggregate stock returns may point out the window of opportunity. For that purpose, this study adds market returns (MktRet) during a six-month interval from 185 trading days prior to IPO and 5 days before the formal listing of the IPO firm. This study assumes that the likelihood of employing discounted cash flow method increases when the aggregate stock market returns before going public are high. The assumption of dividend discount model contrasts with the discounted cash flow model because DDM is used when aggregate stock market returns are poor. Baker and Wurgler (2004) proposed a theory that investors pay more attention to buying those stocks that pay dividends on a regular basis. Therefore, it is anticipated that during the bearish momentum, investors are more likely to be purchased dividend-paying stocks when aggregate stock market returns are in declining trend.

Roosenboom (2007) argues that the investors are uncertain about fundamentals of securities when aggregate market returns are highly volatile. In this study, standard deviation (SD) of benchmark index is included during a six-month interval from 185 trading days prior to IPO and 5 days before the formal listing of IPO firm. The investment bankers choose a direct valuation method to cater the investors demand by controlling the impact of market volatility. Therefore, it is anticipated that the direct valuation methods, such as the discounted cash flow and dividend discount model, are to be used more often when market returns are more volatile prior to IPO. In this model, underwriter reputation is included as a control variable. This study employs the underwriter market share as a proxy for underwriter reputation (URep). Following Roosenboom (2012) and Ljungqvist and Wilhelm (2002), the dummy variable is used for underwriter reputation, taking a value of 1 for prestigious underwriters and 0 for less reputed underwriters. Carter and Manaster (1990) suggest that the prestigious underwriters are considered to be more expert in valuing IPO firms. The magnitude of underwriter reputation may impact the choice of valuation method although this study unable to find any particular prior prediction regarding the valuation model by prestigious underwriters. The rapidly growing firms offer a large portion of their shares in general public offerings to finance their future expansions and investments while mature firms small part in the public offering. Therefore, if the value of the dilution factor (DilutionFactr) is large then underwriters prefer to use the multiples valuation method and the direct valuation methods for small dilution factors.

\subsubsection{The Value Relevancy Model}

In this part, we examine OLS regression to test the valuation relevancy and predictive power of each valuation method by conducting a Wald-test to probe whether the intercept term is statistically different from zero and the slope coefficient statistically different from one. This methodology assists to examine the ability of value relevancy to explain cross-sectional variation in the market values. The valuation theories conjecture that the market value of IPO firms is directly proportional to pre-IPO value estimates examined by investment banks. If the valuation models produce unbiased estimates of market values then the intercept would be equals zero and the slope coefficient equals one. According 
to Roosenboom (2012), Deloof et al. (2009) and Cassia et al. (2004) for the purpose of valuation relevancy, a more broad-spectrum regression model may be used as

$$
\log \left(\text { Market Value }_{i}\right)=\beta_{0}+\beta_{1} \log \left(\text { Estimated Value }_{i, p r e I P O}\right)+\varepsilon_{i}
$$

where Estimated Value $e_{\text {,preIPO }}$ is the value estimates determined by underwriters using valuation methods when valuing IPO firm ' $i$ ' and Market Value is the closing price of the first trading day in the stock market, $\beta_{0}$ and $\beta_{1}$ are the intercept and the slope of a regression model, respectively, and $\varepsilon_{i}$ is the pricing error. In the Equation (3), the natural logarithm of Market Value is used as a dependent variable and the natural logarithm of Estimated Value calculated through several valuation models used as the independent variable as discussed in the earlier.

\section{Results and Discussion}

This study addresses the research objective of "to investigate the firm-specific characteristics and stock market-related factors that had influenced the choice of valuation methods when valuing IPOs." This study also reviews that how underwriters add the value estimates derived through valuation methods to determine the fair value estimates and set the offer price of a given IPO.

\subsection{Descriptive Statistics}

In relation to firm-specific characteristics used in the binary logit and cross-sectional regression models; this study provided the descriptive statistics in Table 3 . The on average firm size is 28,258 (millions PKR) but the values of percentiles and standard deviation depicts that most of the firms are smaller in size due to greater variability in the firm size. Another implication of this lump is due to several privatization IPOs carried out in the sample. The average age of newly-listed firms is 15 years which symbolize that most IPO firms are young in age. The average (median) of AIP is $40.08 \%(36.98 \%)$ tend to indicate that more than $50 \%$ firms' fixed assets are below the median. In this study, about $40 \%$ IPOs belong to financial services and telecommunication sectors that invest more in working capital rather than fixed tangible assets. The average (median) forecasted profitability is equal to $20.67 \%$ $(16.16 \%)$ before the IPO. Only 15 out of 88 IPO firms are predicted to document losses in the latest financial year and our study not lead by loss-making companies. This indicates that the most profitable firms decide to go public to raise long-term equity capital to capitalize on the future opportunities. The average (median) predicted sales growth is $42.17 \%$ (18.90\%). The results are consistent with the argument of rapidly growing firmsthatface challenges of cash imbalances in the short to medium term because their capital investments are more than the cash inflows. The average (median) dividend payout is equal to $20.25 \%(0 \%)$ indicates that the only few firms 36 out of 88 have been announced the dividends in latest financial year before the IPOs. The average (median) market returns before the IPOs is $7.86 \%(9.47 \%)$, positive returns before the IPO open the 'window of opportunity' to growth companies. The average (median) ex-ante uncertainty equals $1.30 \%(1.16 \%)$ in the preceding months before the IPOs. The average (median) dilution factor equals $23.32 \%(25 \%)$ at the time of formal listing. The large fraction of equity sold to the general public indicates that poor quality firms and underwriters prefer to use multiples valuation to value a firm's equity as per needed valuations.

Table 4 presents the summary of valuation methods disclosed by Pakistani underwriters in the prospectuses of 88 IPOs listed on PSX during the sample period. In practice, most underwriters publish only widely accepted valuation models rather than the unconventional equity valuation methods as highlighted by Fernandez $(2001)^{4}$. It has been observed that the multiples valuation

4 Fernandez (2001) talks about the valuation of Terra-Lycos (internet service provider) in 2000 by a several investment banks, which use weighted-averages of inquisitive combination of different multiples on the basis of such as number of inhabitants, gross national product (GNP) per capita, enterprise-value (EV) per page view, capitalization per subscriber and capitalization per page view. 
approach is used almost $74 \%$ of the times. This fraction is similar observe in France (Roosenboom 2007) and Belgium (Deloof et al. 2009). The most admired multiples based on industry and/or size is the price-book ratio, followed by the price-earnings ratio, price-sales ratio and price-EBITDA ratio. The lead underwriters calculate the fair value estimates by taking the product of average (or median) of specific accounting-based information multiple with the matching accounting-based information about the IPO firm. Table 4 documents that discounted cash flow model is used to estimate the fair value estimates of IPO firm's equity in 20 times $(22.73 \%)$ and the dividend discount model is used to estimate the intrinsic value of the IPO firm's equity in 15 times $(17.07 \%)$. The percentage of the DCF model used in emerging economy is greater than the US lead underwriters (Houston et al. 2006; Asquith et al. 2005) but less than the France lead underwriters (Roosenboom 2012).

Table 3. Descriptive Statistics.

\begin{tabular}{ccccccccc}
\hline \multirow{2}{*}{ Variable Name } & \multirow{2}{*}{ Mean } & \multirow{2}{*}{ Min } & \multicolumn{3}{c}{ Percentiles } & \multirow{2}{*}{ Max } & SD & \multirow{2}{*}{ N } \\
\cline { 5 - 6 } & & & 25th & 50th & 75th & & & \\
\hline Total Assets (millions) & 28.25 & 15.00 & 1235 & 2715 & 16.67 & 691.99 & 94.57 & 88 \\
Firm Age (Years) & 15.12 & 1.30 & 3.50 & 8.00 & 19.00 & 78.00 & 17.61 & 88 \\
Property, Plant \& Equip. (\%) & 40.08 & 0.001 & 8.964 & 36.98 & 68.19 & 99.863 & 31.46 & 88 \\
Profitability (\%) & 20.67 & -165.59 & 4.013 & 16.16 & 36.34 & 137.52 & 38.21 & 88 \\
Sales Growth (\%) & 42.17 & -48.338 & 0.00 & 18.90 & 55.89 & 740.68 & 95.07 & 88 \\
Dividend Payout (\%) & 20.25 & 0.000 & 0.00 & 0.00 & 41.63 & 100.00 & 29.22 & 88 \\
Market Returns (\%) & 7.859 & -63.807 & 1.036 & 9.468 & 17.70 & 51.850 & 19.27 & 88 \\
Ex-ante Uncertainty (\%) & 1.297 & 0.667 & 0.924 & 1.159 & 1.586 & 2.538 & 0.503 & 88 \\
Dilution Factor (\%) & 23.31 & 2.500 & 14.92 & 25.00 & 27.87 & 50.000 & 10.71 & 88 \\
\hline
\end{tabular}

Table 4. Valuation Methods used by Underwriters.

\begin{tabular}{ccc}
\hline Valuation Method & Frequency & Percentage \\
\hline Multiples & 65 & 73.864 \\
- Price/Earnings Ratio & 36 & 40.909 \\
- Price/Book Ratio & 51 & 57.955 \\
- Price/Sales Ratio & 1 & 1.136 \\
- Price/EBITDA Ratio & 1 & 1.136 \\
Discounted Cash Flow & 20 & 22.727 \\
Dividend Discount Model & 15 & 17.073 \\
\hline
\end{tabular}

Source: Compiled from prospectus documents.

Practically, the multiples valuation is frequently used by investment banks to value IPO firm's equity while some irregularities have been observed with this valuation method. First, from a theoretical viewpoint, the economic rationale of multiples is open to discussion as the analysis is not derived by the fundamentals like future cash flows, growth opportunities and predicted uncertainties which notify regarding value independent of market prices. Second, the multiples valuation method assumes that the market is efficient in order to determine prices for the comparables. In addition, the multiples valuation method is static in nature in most of the cases, while DCF is an appropriate measure for a dynamic business environment. From a conceptual viewpoint, the multiples valuation technique has a problem in implementation. It is quite difficult to recognize comparable firms having similar business operations and firm-specific financial characteristics. The multiples valuation leaves too much room for 'playing with mirrors' and open freedom for lead underwriters to get a needed valuation. Penman (2007) argues that different multiples offer different valuation estimates and it is difficult to assess which is most unbiased and accurate. Pratt et al. (2000) highlight that the investment banks fail to make necessary modifications to comparable firms' financial statements and an easy dependence on the median or mean of comparable firms' multiples to estimate incorrect results. Lie and Lie (2002) discuss that the DFCF is required sturdy work to estimate appropriate forward cash flows and discount rates rather than multiples valuation estimates. 


\subsection{The Analysis of the Selection of Valuation Methods}

In this section, this study investigates the firm-specific characteristics and stock market-related factors that had influenced the choice of each valuation method used by underwriters when pricing IPOs. In this analysis, the valuation methods employed by underwriter are used as dependent variables and $t$-statistics have been estimated through Huber/White standard errors.

In the DDM valuation method analysis, Table 5 reports that Firm age is negatively linked with the choice of DDM valuation method and these findings contradict with the assumption of DDM valuation theory that the underwriters prefer to use DDM when valuing older firms. These findings contrary to Deloof et al. (2009) argue as the dividend discount model is the best measure of valuing stable and large firms. The coefficient of Total Assets appears to be positive but statistically insignificant. The results of firm size determinant provide the supporting evidence of proposed hypothesis which presents the positive association between the firm size and choice of DDM valuation method. The Property, plant and equipment is also positively linked with DDM valuation method and underwriters are more likely to use DDM when valuing large firms. The finding reveals that the coefficient of Operating Profitability appears to be negative and this implies that the underwriters less likely to use DDM when valuing firms which are relatively profitable in the IPO year. On the similar pattern, the coefficient of Sales Growth appears to be negative and statistically insignificant. Underwriters do not use the DDM valuation method when firms' sales growth is relatively less. The findings reveal that underwriters prefer to choose DDM valuation method when firms had offered cash and/or stock payouts in trailing years because the coefficient of Dividend Payout appears to be positive (0.0408) and strongly significant at the $95 \%$ level of confidence. These findings are in sequence with working hypothesis and comparable with existing literature (Bhattacharya 1979; Damodaran 1994; Roosenboom 2007; Deloof et al. 2009; Abdulai 2015). The coefficient of Technology firms is positive but statistically insignificant; underwriters do not use direct valuation for technology firms and these results are inconsistent with the DDM valuation theory and Roosenboom (2007) findings. The coefficient of Market returns is positively linked with the preference of DDM valuation method but statistically insignificant. The findings conjecture that the possible investors may more interested in high dividend paying firms when aggregate stock market returns are higher. The coefficient of $E x$-ante uncertainty appears to be negative and statistically insignificant. This implies that the underwriters do not use the DDM valuation method when aggregate market volatility is large before the IPOs. The coefficient of Dilution Factor appears to be negative. The coefficient of Underwriter Reputation appears to be positive (1.9519) and strongly significant at the $99 \%$ level of confidence. This implies that the reputed underwriters prefer to use direct valuation than the relative multiples to leave less money on the table during the IPO valuation process.

Table 5 presents the DCF valuation analysis and findings reveal that the coefficient of Firm Age appears to be negative (-2.5898) and strongly significant at $95 \%$ level of confidence. This implies that underwriters prefer to use DCF valuation method when pricing young firms. The results of younger firms are consistent with Roosenboom (2007) but contradict with Abdulai (2015) and Beatty and Ritter (1986) as they argue that it is difficult to predict future cash flows for young firms without trailing financial fundamentals. The results reveal thatthecoefficient of Property, Plant $\mathcal{E}$ Equipment appears to be positive (0.0307) and significant at 95\% level of confidence. This implies that underwriters are more likely to use DCF valuation method when firms have placed their more investments as fixed assets. The firms having more assets as fixed assets expected to generate more revenue in future and DCF is considered as a good measure to capitalize predicted future cash flows to estimate the fair value estimates. These findings are consistent in sequence with the proposed hypothesis and findings of Lev (2001) as accounting numbers supposed to be a good estimator of a firm value from tangible assets than the intangible assets. The findings reveal that the coefficient of Operating Profitability appears to be positive (0.0198) and significant at the $90 \%$ level of confidence. This implies that there is a positive association between the operating profitability and underwriter's choice to select DCF to value IPOs. The results are in sequence with the assumption of IPO valuation theory that the profitable firms are valued by direct valuation techniques. Roosenboom (2007) and 
Abdulai (2015) also find the positive associations between the choice of DCF and extent of operating profitability before the IPOs. The predicted sales growth in the IPO year is used as a proxy for growth opportunities. The findings show that the coefficient of Sales Growth appears to be negative $(-0.0220)$ and significant at the $95 \%$ level of confidence. This implies that the rapidly growing firms face challenges of cash imbalances in the short to medium term because their capital investments are more-than the cash inflows. The coefficient of Market Returns appears to be positive (0.043) and statistically significant at 95\% level of confidence. These findings are in sequence of Penman (2001), Roosenboom (2007) and Demirakos et al. (2010). The findings report that the coefficients of Technology based firms and Underwriter Reputation are positively related to the decision of DCF valuation method but found statistically insignificant. This study conjecture that market sentiments before the IPO offered a "window of opportunity" during when market participants are more enthusiastic to purchase risky stocks and more willing to believe the cash flow and discount rate suppositions factoring the DCF model. The findings also highlight that the coefficients of Ex-ante uncertainty and Dilution Factor are negatively linked with the preference of DCF valuation technique. This implies that the market participants may be more uncertain about fundamental values during high ex-ante uncertainty because the DCF method offers information which investors required to estimate the fundamental value of the IPO firms. The findings reveal that the underwriters do not use the DCF valuation method when valuing larger, older and lower growth firms.

Table 5. Results of Binary Logit of Preferred Valuation Methods.

\begin{tabular}{|c|c|c|c|c|c|}
\hline \multirow{2}{*}{ Models } & \multirow{2}{*}{ DDM } & \multirow{2}{*}{ DCF } & \multirow{2}{*}{ Multiples } & \multicolumn{2}{|c|}{ Multiples } \\
\hline & & & & P/E Ratio & P/B Ratio \\
\hline Independent Variables & (1) & (2) & (3) & (4) & (5) \\
\hline Intercept & $\begin{array}{c}-10.9957 \\
(-2.025)^{* *}\end{array}$ & $\begin{array}{l}9.0024 \\
(1.236)\end{array}$ & $\begin{array}{l}-2.7813 \\
(-0.470)\end{array}$ & $\begin{array}{c}-13.4749 \\
(-2.099)^{* * *}\end{array}$ & $\begin{array}{l}4.3583 \\
(0.924)\end{array}$ \\
\hline Total Assets & $\begin{array}{l}0.7851 \\
(1.374)\end{array}$ & $\begin{array}{l}-0.9634 \\
(-1.391)\end{array}$ & $\begin{array}{l}0.2420 \\
(0.435)\end{array}$ & $\begin{array}{l}0.9255 \\
(1.583)\end{array}$ & $\begin{array}{l}-0.3821 \\
(-0.890)\end{array}$ \\
\hline Firm Age & $\begin{array}{l}-0.3841 \\
(-0.394) \\
\end{array}$ & $\begin{array}{c}-2.5898 \\
(-2.323)^{* *}\end{array}$ & $\begin{array}{c}2.4833 \\
(2.328)^{* *}\end{array}$ & $\begin{array}{c}4.4598 \\
(4.188)^{* * *}\end{array}$ & $\begin{array}{l}0.6692 \\
(0.943)\end{array}$ \\
\hline Property, plant \& Equip. & $\begin{array}{l}0.0064 \\
(0.483)\end{array}$ & $\begin{array}{c}0.0307 \\
(2.648)^{* *}\end{array}$ & $\begin{array}{c}-0.0336 \\
(-3.032) * *\end{array}$ & $\begin{array}{c}-0.0216 \\
(-1.779)^{*}\end{array}$ & $\begin{array}{c}-0.0230 \\
(-2.558)^{* *}\end{array}$ \\
\hline Operating Profitability & $\begin{array}{l}-0.0006 \\
(-0.039) \\
\end{array}$ & $\begin{array}{c}0.0198 \\
(1.782)^{*}\end{array}$ & $\begin{array}{l}0.0033 \\
(0.509) \\
\end{array}$ & $\begin{array}{l}0.0125 \\
(1.331) \\
\end{array}$ & $\begin{array}{l}-0.0125 \\
(-1.379) \\
\end{array}$ \\
\hline Sales Growth & $\begin{array}{l}-0.0026 \\
(-0.691) \\
\end{array}$ & $\begin{array}{c}-0.022 \\
(-2.377)^{* *}\end{array}$ & $\begin{array}{l}0.0056 \\
(0.894) \\
\end{array}$ & $\begin{array}{l}0.0001 \\
(0.029) \\
\end{array}$ & $\begin{array}{l}0.0063 \\
(1.149)\end{array}$ \\
\hline Dividend Payout & $\begin{array}{c}0.0408 \\
(2.922) * *\end{array}$ & $\begin{array}{l}-0.0119 \\
(-0.946)\end{array}$ & $\begin{array}{l}-0.0123 \\
(-1.344)\end{array}$ & $\begin{array}{c}-0.0184 \\
(-1.836)\end{array}$ & $\begin{array}{l}-0.0009 \\
(-0.101)\end{array}$ \\
\hline Technology & $\begin{array}{l}1.0477 \\
(1.295)\end{array}$ & $\begin{array}{c}0.675 \\
(0.905)\end{array}$ & $\begin{array}{l}0.0053 \\
(0.007)\end{array}$ & $\begin{array}{l}-0.1599 \\
(-0.214)\end{array}$ & $\begin{array}{l}-0.0806 \\
(-0.138)\end{array}$ \\
\hline Market Returns & $\begin{array}{l}0.0032 \\
(0.143)\end{array}$ & $\begin{array}{c}0.043 \\
(2.398)^{* *}\end{array}$ & $\begin{array}{c}-0.0317 \\
(-1.753)^{*}\end{array}$ & $\begin{array}{c}0.0321 \\
(1.703) \text { * }\end{array}$ & $\begin{array}{c}-0.0244 \\
(-1.667) \text { * }\end{array}$ \\
\hline Ex-ante & $\begin{array}{l}-0.7295 \\
(-0.633)\end{array}$ & $\begin{array}{l}-0.1000 \\
(-0.129)\end{array}$ & $\begin{array}{l}-0.0845 \\
(-0.081)\end{array}$ & $\begin{array}{l}-0.0422 \\
(-0.038)\end{array}$ & $\begin{array}{l}-0.1574 \\
(-0.295)\end{array}$ \\
\hline Underwriter Reputation & $\begin{array}{c}1.9519 \\
(2.631)^{* * *}\end{array}$ & $\begin{array}{l}0.3148 \\
(0.431)\end{array}$ & $\begin{array}{l}0.5258 \\
(0.817)\end{array}$ & $\begin{array}{l}0.7142 \\
(0.984)\end{array}$ & $\begin{array}{l}0.3514 \\
(0.661)\end{array}$ \\
\hline Dilution Factor & $\begin{array}{l}-0.0213 \\
(-0.726) \\
\end{array}$ & $\begin{array}{l}-0.0143 \\
(-0.386) \\
\end{array}$ & $\begin{array}{l}0.0179 \\
(0.483)\end{array}$ & $\begin{array}{l}-0.0266 \\
(-0.649) \\
\end{array}$ & $\begin{array}{l}-0.0010 \\
(-0.032) \\
\end{array}$ \\
\hline McFadden R2 & 0.3797 & 0.3723 & 0.2823 & 0.4349 & 0.1620 \\
\hline LR-Statistic & $26.976^{* * *}$ & $32.857^{* * *}$ & $27.149 * *$ & $51.322^{* * *}$ & 19.225 * \\
\hline Prob(LR-Statistic) & 0.0046 & 0.0005 & 0.0044 & 0.0000 & 0.0572 \\
\hline $\mathrm{N}$ & 88 & 88 & 88 & 88 & 88 \\
\hline
\end{tabular}

The Z-Statistics are within parentheses and calculated on the basis of Robust Huber/White standard errors. ${ }^{* * *}$ Significant at the $1 \%$ level, ${ }^{* *}$ significant at the $5 \%$ level and ${ }^{*}$ significant at the $10 \%$ level. 
Table 5 presents the Multiples valuation analysis and findings reveal that the coefficient of Firm Age appears to be positive (2.4833) and significant at the $95 \%$ level of confidence. This implies that the lead underwriters prefer to choose multiples valuation method when valuing older firms. These results are inconsistent with the proposed hypothesis that older firms are valued by direct valuation methods rather than the comparable firms approach while findings are contrasted with Roosenboom (2007), Deloof et al. (2009), Demirakos et al. (2010) and Kim and Ritter (1999) as they argue that it is difficult to predict future cash flows for young firms without trailing financial fundamentals. The coefficient of Property, Plant \& Equipment appears to be negative (-0.0336) and significant at the $95 \%$ level of confidence. The firms having more assets as fixed expected to generate more revenues in the future and vice versa, multiples technique is considered as a good measure to discount predicted future cash flows to estimate the fair value estimates. These findings are comparable with Abdulai (2015) but contrary to the Roosenboom (2007). The findings show that the coefficient of Market Returns appears to be negative $(-0.0317)$ and significant at the $90 \%$ level of confidence. This implies that underwriters prefer to use relative comparable firms approach to price IPO firms when market sentiments are bearish before the IPO. As consistent with the valuation theories, this study finds that underwriters prefer to use multiples valuation method when IPOs are relatively profitable and positive expected sales growth in the IPO year. The findings reveal that the coefficient of Dividends payout and Market Returns before the IPOs are negatively linked to the selection of multiples valuation method. This implies that only mature and large, profitable firms offer corporate payouts and underwriters are more likely to use multiples when firms are immature in terms of sales and enhancing their business operations. The findings also reveal that the prestigious underwriters opt multiples when pricing IPOs. Underwriters are preferred to use multiples when firms having a large fraction of dilution factor at the time of pricing process. The findings unfold that underwriters are more likely to use multiples valuation method when pricing technology firms.

In this study, underwriters used price-earnings $(\mathrm{P} / \mathrm{E})$ and price-book $(\mathrm{P} / \mathrm{B})$ ratios as multiple valuation measures. Table 5 presents the $\mathrm{P} / \mathrm{E}$ analysis, the statistically significant determinants are firm age, property plant \& equipment, dividend payout and market returns before the IPO. Most of the findings are consistent with multiples valuation analysis and comparable with Deloof et al. (2009) and Demirakos et al. (2010). The findings reveal that the underwriters are more likely to use P/E valuation measure when aggregate stock market returns before the IPO are positive, firms do not have the trailing history of offer corporate payouts, firms having fewer investments as fixed assets and elder firms. The findings report that the $\mathrm{P} / \mathrm{E}$ multiple is positively linked with high operating profitability, high sales growth and the prestigious underwriter factors. On the other side, underwriters prefer to choose a $\mathrm{P} / \mathrm{B}$ valuation measure when aggregate stock market returns are in bearish fashion before the IPO and firms having fewer investments as fixed assets. The findings reveal that the prestigious underwriters are more likely to use both $\mathrm{P} / \mathrm{E}$ and $\mathrm{P} / \mathrm{B}$ multiples during high ex-ante volatility in the market before the IPO. The findings conclude that the fair value of technology firms and positive sales growth firms are drawn from predicted growth opportunities which can easily estimate through multiples valuation approach.

Table 6 presents the analysis of equality of coefficients from two different valuation models. Comparing the coefficient of Total Assets between valuation models indicates that the percentage change between the selection of DDM and DCF valuation models based on firm size is significantly different from each other at the $95 \%$ level of confidence and vice versa for Multiples. The coefficients for Firm age and AIP are statistically significant in DCF and Multiples methods. However, the difference in coefficients between valuation models is also statistically significant from each other. This implies that investment banks more likely to select DCF for young firms, while Multiples for mature firms. On the similar pattern, the coefficient of Sales Growth for DCF is significantly different from DDM and Multiples. The findings reveal that the underwriters select DCF for firms that have negative sales growth before the IPO. The underwriters select DDM for firms that have dividends payout trail and the coefficient of Dividends for DDM is statistically different from DCF and Multiples coefficients. 
The findings are consistent with the valuation theory and Roosenboom (2007). The investment banks are more likely to choose DCF when stock market returns are positive before the IPO, while select Multiples for negative market returns. The coefficient of Market Returns for DCF is statistically significant from Multiples at the $99 \%$ level of confidence.

Table 6. The Equality of Coefficients from Different Valuation Models' Test Analysis.

\begin{tabular}{ccccccc}
\hline Models & \multicolumn{3}{c}{ Coefficients } & \multicolumn{3}{c}{ Z Test } \\
\cline { 2 - 7 } & DDM & DCF & Multi & DDM, DCF & DDM, Multi & DCF, Multi \\
\hline Independent Variables & $-\mathbf{1}$ & $-\mathbf{2}$ & $-\mathbf{3}$ & $\mathbf{( 1 , 2 )}$ & $\mathbf{( 1 , 3 )}$ & $\mathbf{( 2 , 3 )}$ \\
\hline Intercept & $-10.9957^{* *}$ & 9.0024 & -2.7813 & $-2.2014^{* *}$ & -1.0233 & 1.2562 \\
Total Assets & 0.7851 & -0.9634 & 0.2420 & $1.9469^{* *}$ & 0.6814 & -1.3574 \\
Firm Age & -0.3841 & $-2.5898^{* *}$ & $2.4833^{* *}$ & 1.4894 & $-1.9843^{* *}$ & $-3.288^{* * *}$ \\
Property, plant \& Equip. & 0.0064 & $0.0307^{* *}$ & $-0.0336^{* *}$ & -1.3848 & $2.3232^{* *}$ & $4.0059^{* * *}$ \\
Operating Profitability & -0.0006 & $0.0198^{*}$ & 0.0033 & -1.0944 & -0.2389 & 1.2841 \\
Sales Growth & -0.0026 & $-0.022^{* *}$ & 0.0056 & $1.9438^{* *}$ & -1.1272 & $-2.4687^{* * *}$ \\
Dividend Payout & $0.0408^{* *}$ & -0.0119 & -0.0123 & $2.806^{* * *}$ & $3.1805^{* * *}$ & 0.0256 \\
Technology & 1.0477 & 0.6750 & 0.0053 & 0.3387 & 0.9578 & 0.6424 \\
Market Returns & 0.0032 & $0.043^{* *}$ & $-0.0317^{*}$ & -1.2203 & 1.2053 & $2.5174^{* * *}$ \\
Ex-ante & -0.7295 & -0.1000 & -0.0845 & -0.4535 & -0.4157 & -0.0119 \\
Underwriter Reputation & 1.9519 & 0.3148 & 0.5258 & 1.5731 & 1.4523 & -0.2168 \\
Dilution Factor & -0.0213 & -0.0143 & 0.0179 & -0.1482 & -0.8296 & -0.6137 \\
McFadden R2 & 0.3797 & 0.3723 & 0.2823 & & & \\
LR-Statistic & $26.976^{* * *}$ & $32.857^{* * *}$ & $27.149 *$ & & & \\
Prob(LR-Statistic) & 0.0046 & 0.0005 & 0.0044 & & & \\
N & 88 & 88 & 88 & & &
\end{tabular}

\subsection{The Analysis of Value Relevancy of Each Valuation Method}

This study examines the predictive power of pre-IPO value estimates of each valuation method to explain the cross-sectional variation in the market values. To explain this value relevancy, this study employed the Wald-test to test the joint hypothesis that the intercept term equal to zero and the slope coefficient equal to one. If the underwriter's estimates produce unbiased estimates of market values, then the intercept should be equals zero and the slope coefficient equals one. In the value relevancy models, the natural logarithm of Market Value of IPO firms used as a dependent variable and natural logarithm of Estimated Value disclosed in the prospectus for each valuation model as the independent variable. In Table 7, the t-statistics estimated through White (1980) heteroscedastic and standard errors are reported in the parentheses.

Table 7 documents the findings of predictive power of each valuation method and value relevancy by conducting OLS regressions and Wald-statistic respectively. The findings reveal that we can reject the hypothesis that the slope coefficient equal to one for all valuation models and none of the valuation models produces an unbiased estimate of market values. However, the Wald-statistic illustrates that the joint hypothesis of an intercept equals zero and a slope coefficient equals one is rejected for each valuation model. An investigation of predictive power for each valuation method, Table 7 shows that the multiples (importantly $\mathrm{P} / \mathrm{B}$ measure) valuation method has the highest predictive power, while discounted cash flow method has lowest predictive power to market value estimates. These findings are consistent with the (Roosenboom 2012; Cassia et al. 2004; Kim and Ritter 1999).

These findings raise the question of why investment banks deliberately overestimate the fair-value estimates than market value estimates. One of the key reasons to keep this conduct is because it permits underwriters to offer a large discount to market participants. Ritter and Welch (2002) argue that the underwriters may not use a model that comes up with an offer price as close to the first trading day closing price because to generate great initial returns or leave a good taste in investors' mouth. This envisages that impetuous biased valuations are correlated with large offer price discounts. 
We certainly estimate a high association of larger discounts with underwriters' reputation, auction type and the valuation methodologies adopted as well (see Table 8).

Table 7. The Analysis of Value Relevancy through Regressions.

\begin{tabular}{|c|c|c|c|c|c|}
\hline \multirow{2}{*}{ Indep. Variable } & \multicolumn{2}{|c|}{ Parameter } & \multirow{2}{*}{ Adj. R2 (\%) } & \multirow{2}{*}{$\mathbf{N}$} & \multirow{2}{*}{ Wald Test } \\
\hline & Intercept & Slop & & & \\
\hline Dividend Discount Model & $\begin{array}{l}0.0354 \\
(0.102)\end{array}$ & $\begin{array}{c}0.9856 \\
(4.317)^{* *}\end{array}$ & 73.00 & 15 & 0.0710 \\
\hline Discounted Cash Flow & $\begin{array}{l}0.2869 \\
(1.535)\end{array}$ & $\begin{array}{c}0.7846 \\
(5.670)^{* * *}\end{array}$ & 47.94 & 20 & 1.2122 \\
\hline Multiples Valuation & $\begin{array}{l}0.0423 \\
(0.619)\end{array}$ & $\begin{array}{c}0.9561 \\
(18.985)^{* * *}\end{array}$ & 83.25 & 65 & 0.7378 \\
\hline P/E Ratio & $\begin{array}{l}0.0992 \\
(0.741)\end{array}$ & $\begin{array}{c}0.9346 \\
(11.534)^{* * *}\end{array}$ & 72.60 & 36 & 0.3521 \\
\hline P/B Ratio & $\begin{array}{l}0.1014 \\
(1.624)\end{array}$ & $\begin{array}{c}0.9084 \\
(19.965)^{* * *}\end{array}$ & 86.41 & 51 & $2.5404 *$ \\
\hline Fair Value Estimates & $\begin{array}{l}0.1047 \\
(1.570)\end{array}$ & $\begin{array}{c}0.9168 \\
(18.990)^{* * * *}\end{array}$ & 81.58 & 88 & 1.5652 \\
\hline
\end{tabular}

*** Significance at $10 \%$ level, ${ }^{* *}$ significance at $5 \%$ level, ${ }^{*}$ significance at $1 \%$ level.

Table 8. Underpricing and Underwriter's deliberate discount Analysis.

\begin{tabular}{|c|c|c|c|c|c|c|c|}
\hline Panel A & & & & & & & \\
\hline \multirow{2}{*}{ Underwriters } & \multirow{2}{*}{$\mathbf{N}$} & \multicolumn{3}{|c|}{ Deliberate Discount } & \multicolumn{3}{|c|}{ Underpricing } \\
\hline & & Mean & Median & SD & Mean & Median & SD \\
\hline Low Reputed & 30 & $0.409 * * *$ & 0.306 & 0.389 & $0.482^{* * *}$ & 0.150 & 0.762 \\
\hline High Reputed & 58 & $0.274^{* * *}$ & 0.196 & 0.481 & $0.235^{* * *}$ & 0.101 & 0.473 \\
\hline Wilcoxon-Mann/Whitney Test & & & $1.8442 *$ & & & 0.9771 & \\
\hline \multicolumn{8}{|l|}{ Panel B } \\
\hline \multirow{2}{*}{ Auction } & \multirow{2}{*}{$\mathbf{N}$} & \multicolumn{3}{|c|}{ Deliberate Discount } & \multicolumn{3}{|c|}{ Underpricing } \\
\hline & & Mean & Median & SD & Mean & Median & SD \\
\hline Fixed Price & 66 & $0.370^{* * *}$ & 0.326 & 0.420 & $0.398^{* * *}$ & 0.175 & 0.663 \\
\hline BookBuilding & 22 & 0.172 & 0.052 & 0.525 & $0.085^{* *}$ & 0.026 & 0.165 \\
\hline Wilcoxon-Mann/Whitney Test & & & $2.822 * *$ & & & $1.966^{*}$ & \\
\hline \multicolumn{8}{|l|}{ Panel C } \\
\hline \multirow{2}{*}{ Valuation Methodology } & \multirow{2}{*}{$\mathbf{N}$} & \multicolumn{3}{|c|}{ Deliberate Discount } & \multicolumn{3}{|c|}{ Underpricing } \\
\hline & & Mean & Median & SD & Mean & Median & SD \\
\hline Direct Valuation & 33 & $0.285^{* * *}$ & 0.200 & 0.345 & $0.447^{* * *}$ & 0.200 & 0.757 \\
\hline Multiples Valuation & 65 & $0.355^{* * *}$ & 0.274 & 0.494 & $0.327^{* * *}$ & 0.138 & 0.550 \\
\hline Wilcoxon-Mann/Whitney Test & & & 0.6828 & & & 0.5605 & \\
\hline
\end{tabular}

*** Significance at $10 \%$ level, ${ }^{* *}$ Significance at $5 \%$ level, ${ }^{*}$ Significance at $1 \%$ level.

We find that prestigious underwriters produce less offer price discounts than low reputed. These findings are consistent with existing literature (Jenkinson et al. 2016; Reber and Vencappa, 2016) arguments that prestigious underwriters should have an advantage in information production because of a large network with high net-worth institutions and/or individuals resulted in greater price revision in the auction and lower price volatility on the first trading day. We find that institutional investors, who are well-informed, set higher prices due to large participation in the bookbuilding auction than IPOs followed by a fixed-price auction. So, the extent of deliberate discounts is controlled in the 
bookbuilding auction than the fixed-price auction. We find that investment banks choose comparable peers that have higher multiples to offer large price discounts to attract more participation in the bidding auction, while direct valuation methods (e.g., DDM, DCF) produce more rigorous estimates. Paleari et al. (2014) argue that underwriters offer higher deliberate discount relative to peers disclosed in the prospectus is because when they select comparable firms with the highest valuation multiples. Their findings conjecture that comparable firms published in prospectuses exhibit.

\section{Summary and Conclusions}

The existing literature is thin about how investment banks choose the valuation models when pricing IPOs. This article intends to fill this research gap. In this study, data is hand collected from the prospectus documents that provide distinct access to thorough valuation analysis information for a sample of 88 IPOs on PSX during the period 2000-2016. The key purpose of this study is to investigate that how do lead under writers to choose valuation models and value relevancy of each valuation model in the IPOs pricing context?

It has been observed that Pakistani underwriters repeatedly used discounted cash flow, the dividend discount model and multiples valuation methods to value firms they bring public. The dividend discount model is preferred by underwriters when valuing firms that offer major part of their incomes as a corporate payout to its existing shareholders. In the Pakistani primary market, the preference of DDM should cater the demand of dividends paying equities. The discounted cash flow method is used when valuing young firms, the firms gradually increasing their fixed assets by investing more in capital expenditures, profitable and rapidly growing firms. This study finds that the Pakistani lead underwriters prefer to select multiples valuation method when valuing mature firms, the firms having less assets-in-tangibility and during bearish market sentiment phase.

In the value relevancy of valuation model analysis, the findings reveal that the multiples-especially the $\mathrm{P} / \mathrm{B}$ ratio-valuation method has the highest predictive power for market value estimates but the DCF has less predicting power. On the other side, the findings of a Wald-statistic test of joint hypothesis, none of the valuation methods produce an unbiased estimate of market value. The findings of cross-sectional regression and Wald test are consistent with the existing literature (Roosenboom 2012; Cassia et al. 2004; Kim and Ritter 1999). Due to limited sample size of study, the generality of the results may be different for other countries.

In future, scholars can conduct a survey among investment banks/underwriters, along with the valuation information disclosed in the prospectuses, to shed more light on why and when investment banks employ a specific valuation method. Further, the studies regarding the selection and accuracy of valuation methods deserve more attention in similar contexts such as mergers \& acquisitions and private equity investments. According to the existing literature, the capital expenditures used as a proxy for a need for financing, growth and cost of credit is still debatable. Academic researchers have been discussed the importance of macroeconomic and capital market determinants when issuing firms motivated to raise capital for new projects. In future, other variables can be added in analysis such as asset risk, total productivity factor, exchange rate and GDP growth used by developed countries researchers.

Author Contributions: Conceptualization, A.R. and M.K.S.; Methodology, S.-U.D.; Software, S.-U.D.; Formal Analysis, A.R. and S.-U.D.; Resources, M.I.; Data Curation, M.I.; Writing-Original Draft Preparation, A.R.; Writing-Review \& Editing, A.R.; Supervision, M.K.S.

Funding: This research funded by "Institutions Through the Knowledge Unlatched Initiative".

Acknowledgments: The authors would like to thank the editor and the anonymous reviewers for their valuable comments and suggestions.

Conflicts of Interest: The authors declare no conflict of interest. 


\section{References}

Abdulai, Mohammed Sani. 2015. Valuation, Pricing and Performance of Initial Public Offerings on the Ghana Stock Exchange. Ph.D. dissertation, Walden University, Minneapolis, MN, USA, March 30.

Alford, Andrew W. 1992. The Effect of the Set of Comparable Firms on the Accuracy of the Price-Earnings Valuation Method. Journal of Accounting Research 30: 94-108. [CrossRef]

Asquith, Paul, Michael B. Mikhail, and Andrea S. Au. 2005. Information Content of Equity Analyst Reports. Journal of Financial Economics 75: 245-82. [CrossRef]

Baker, Malcolm, and Jaffrey Wurgler. 2004. A Catering Theory of Dividends. Journal of Finance 59: 1125-65. [CrossRef]

Barker, Richard G. 1999a. The Role of Dividends in Valuation Models Used by Analysts and Fund Managers. The European Accounting Review 8: 195-218. [CrossRef]

Barker, Richard G. 1999b. Survey and Market-Based Evidence of Industry-Dependence in Analysts' Preferences between the Dividend Yield and Price-Earnings Ratio Valuation Models. Journal of Business Finance EAccounting 26: 393-418.

Bartov, Eli, Partha Mohanram, and Chandrakanth Seethamraju. 2002. Valuation of internet stocks-An IPO perspective. Journal of Accounting Research 40: 321-46. [CrossRef]

Beatty, Randolph P., and Jay R. Ritter. 1986. Investment banking, reputation and the underpricing of initial public offerings. Journal of Financial Economics 15: 213-32. [CrossRef]

Berkman, Henk, Michael E. Bradbury, and Jason Ferguson. 2000. The accuracy of price-earnings and is counted cash flow methods of IPO equity valuation. Journal of International Financial Management EAccounting 11: 71-83.

Bhattacharya, Sudipto. 1979. Imperfect Information, Dividend Policy and the 'Bird in the Hand' Fallacy. The Bell Journal of Economics 10: 259-70. [CrossRef]

Bhojraj, Sanjeev, and Charles M. C. Lee. 2002. Who is my peer? A valuation-based approach to the selection of comparable firms. Journal of Accounting Research 40: 407-39. [CrossRef]

Boatsman, James R., and Elba F. Baskin. 1981. Asset valuation with Incomplete Markets. Accounting Review 56: 38-53.

Bradley, Daniel J., Bradford D. Jordan, and Jay R. Ritter. 2003. The Quiet Period Goes out with a Bang. Journal of Finance 58: 1-36. [CrossRef]

Bradshaw, Mark T. 2002. The Use of Target Prices to Justify Sell-Side Analysts' Stock Recommendations. Accounting Horizons 16: 27-41. [CrossRef]

Campbell, Cynthia J., S. Ghon Rhee, Yan Du, and Ning Tang. 2008. Market Sentiment, IPO Underpricing and Valuation. Available online: https:/ / ssrn.com/abstract=1108540 (accessed on 2 May 2017).

Carter, Richard, and Steven Manaster. 1990. Initial public offerings and underwriter reputation. Journal of Finance 45: 1045-67. [CrossRef]

Cassia, Lucio, Stefano Paleari, and Silvio Vismara. 2004. The valuation of firms listed on the nuovomercato: The peer comparables approach. Advance Financial Economics 10: 113-29.

Chang, Kuo-Ping, and Yu Min Tang. 2007. Pricing Taiwan's initial public offerings. Asia-Pacific Journal of Accounting E Economics 14: 69-84.

Chang, Eric C., Yan Luo, and Jinjuan Ren. 2013. Cross-listing and pricing efficiency: The informational and anchoring role played by the reference price. Journal of Banking $\mathcal{E}$ Finance 37: 4449-64.

Chen, Gongmeng, and Michael Firth. 1999. The accuracy of profit forecasts and their roles and associations with IPO firm valuations. Journal of International Financial Management EAccounting 10: 202-26.

Clogg, Clifford C., Eva Petkova, and Adamantios Haritou. 1995. Statistical methods for comparing regression coefficients between models. American Journal of Sociology 100: 1261-93. [CrossRef]

Colaco, Hugh M. J., Amedeo De Cesari, and Shantaram P. Hegde. 2013. Retail investor sentiment and IPO valuation. The European Journal of Finance 24: 1-34.

Colaco, Hugh M.J., Amedeo De Cesari, and Shantaram P. Hegde. 2017. The waiting period of initial public offerings. The European Journal of Finance 24: 363-90. [CrossRef]

Koller, Tim, Marc Goedhart, and David Wessels. 2000. Valuation: Measuring and Managing the Value of Companies. New York: McKinsey and Company, Inc., Hoboken: John Wiley \& Sons. 
Damodaran, Aswath. 1994. Damodaran on Valuation: Security Analysis for Investment and Corporate Finance, Buch. New York: Wiley.

Damodaran, Aswth. 2005. Valuation Approaches and Metrics: A Survey of the Theory and Evidence. New York: Now Publisher New York.

DeAngelo, Linda Elizabeth. 1990. Equity Valuation and Corporate Control. Accounting Review 65: 93-112.

Deloof, Marc, Wouter De Maeseneire, and Koen Inghelbrecht. 2002. TheValuation of IPOs by Investment Banks and the Stock Market: Empirical Evidence. Antwerp: Department of Applied Economics, UFSIA-RUCA, University of Antwerp.

Deloof, Marc, Wouter De Maeseneire, and Koen Inghelbrecht. 2009. How do investment banks value initial public offerings (IPOs)? Journal of Business Finance \& Accounting 36: 130-60.

Demirakos, Efthimios, Norman C. Strong, and Martin Walker. 2004. What Valuation Models Do Analysts Use? Accounting Horizons 18: 221-40. [CrossRef]

Demirakos, Efthimios, Norman C. Strong, and Martin Walker. 2010. Does valuation model choice affect target price accuracy? European Accounting Review 19: 35-72. [CrossRef]

Fernandez, Pablo. 2001. Internet Valuations: The Case of Terra-Lycos. Working Paper. Barcelona: IESE Business School.

Francis, Jennifer, Per Olsson, and Dennis R. Oswald. 2000. Comparing the accuracy and explainability of dividend, free cash flow and abnormal earnings equity value estimates. Journal of Accounting Research 38: 45-70. [CrossRef]

Gilson, Stuart C., Edith S. Hotchkiss, and Richard S. Ruback. 2000. Valuation of bankrupt firms. Review of Financial Studies 13: 43-74. [CrossRef]

Glaum, Martin, and Nico Friedrich. 2006. After the Bubble: Valuation of Telecommunication Companies by Financial Analysts. Journal of International Financial Management $\mathcal{E}$ Accounting 17: 160-74.

Goh, Chin Fei, Amran Rasli, Krzyszof Dziekonski, and Saif-ur-Rehman Khan. 2015. Market-based Valuation Multiples: Evidence from Agribusiness Sector. Pertanika Journal of Social Sciences E Humanities 23: 209-22.

Gonoupolis, Dimitrios. 2003. Accuracy of Management Earnings Forecast in IPO Prospectuses. Working Paper. Guildford: University of Surrey.

Hearn, Bruce. 2011. The performance and the effects of family control in North African IPOs. International Review of Financial Analysis 20: 140-51. [CrossRef]

Herawati, Aty, Noer Azam Achsani, Sri Hartoyo, and Roy Sembel. 2017. IPO company stock valuation analysis 2000-2014. International Journal of Organizational Innovation 9: 72-132.

How, Janice, Jennifer Lam, and Julian Yeo. 2007. The use of the comparable firm approach in valuing Australian IPOs. International Review of Financial Analysis 16: 99-115. [CrossRef]

Houston, Joel, Christopher James, and Jason Karceski. 2006. What a difference a month makes: Stock analyst valuations following initial public offerings. Journal of Financial \&Quantitative Analysis 41: 111-37.

Ivashkovskaya, Irina, and Ivan Kuznetsov. 2007. An empirical study of country risk adjustments to market multiples valuation in emerging markets: the case for Russia. E-Journal Corporate Finance 3: 26-52.

Jenkinson, Tim, Howard Jones, and Felix Suntheim. 2016. Quid Pro Quo? What Factors Influence IPO Allocations to Investors? Journal of Finance. [CrossRef]

Jog, Vijay, and Bruce J. McConomy. 2003. Voluntary disclosure of management earnings forecasts in IPO prospectuses. Journal of Business Finance $\mathcal{E}$ Accounting 30: 125-68.

Kaplan, Steven N., and Richard S. Ruback. 1995. The valuation of cash flow forecasts: An empirical analysis. Journal of Finance 50: 1059-93. [CrossRef]

Kim, Moonchul, and Jay R. Ritter. 1999. Valuing IPOs. Journal of Financial Economics 53: 409-37. [CrossRef]

Lev, Baruch. 2001. Intangibles: Management, Measurement and Reporting. Washington: Brookings Institution Press.

Lie, Erik, and Heidi J. Lie. 2002. Multiples Used to Estimate Corporate Value. Financial Analysts Journal 58: 44-54. [CrossRef]

Ljungqvist, Alexander P., and William J. Wilhelm Jr. 2002. IPO allocations: Discriminatory or discretionary? Journal of Financial Economics 65: 167-201. [CrossRef]

Nwude, Chuke. 2010. Valuation and Pricing of Equity Securities in an Emerging Stock Market: Evidence from Nigerian Banking Sector. Available online: https: / / ssrn.com/abstract=1649439 (accessed on 7 June 2016).

Paleari, Stefano, and Silvio Vismara. 2007. Over-optimism when pricing IPOs. Managerial Finance 33: 352-67. [CrossRef] 
Paleari, Stefano, Andrea Signori, and Silvio Vismara. 2014. How do underwriters select peers when valuing IPOs? Financial Management 43: 731-55. [CrossRef]

Penman, Stephen H. 2001. Financial Statement Analysis and Security Valuation. New York: McGraw-Gill International Edition.

Penman, Stephen. 2007. Financial Statement Analysis and Security Valuation, 3rd ed. New York: McGraw-Hill.

Pereiro, Luis E. 2006. The practice of investment valuation in emerging markets: Evidence from Argentina. Journal of Multinational Financial Management 16: 160-83. [CrossRef]

Pratt, Shannon, Robert Reilly, and Robert Schweihs. 2000. Valuing a Business, 4th ed. New York: McGraw-Hill.

Purnanandam, Amiyatosh K., and Bhaskaran Swaminathan. 2004. Are IPOs really underpriced? Review of Financial Studies 17: 811-48. [CrossRef]

Rasheed, Abdul, and Muhammad Khalid Sohail. 2019. Why firms decide to go public? A case study of Karachi Stock Exchange. Pakistan Business Review 21: 2569-82.

Reber, Beat, and Dev Vencappa. 2016. Deliberate premarket underpricing and aftermarket mispricing: New insights on IPO pricing. International Review of Financial Analysis 44: 18-33. [CrossRef]

Ritter, Jay R. 1984. The 'Hot' Issue Market of 1980. Journal of Business 57: 215-40. [CrossRef]

Ritter, Jay, and Ivo Welch. 2002. A review of IPO activity, pricing and allocations. Journal ofFinance 57: 1795-828. [CrossRef]

Roosenboom, Peter. 2007. How Do Underwriters Value Initial Public Offerings? An Empirical Analysis of the French IPO Market. Contemporary Accounting Research 24: 1217-43. [CrossRef]

Roosenboom, Peter. 2012. Valuing and pricing IPOs. Journal of Banking E Finance 36: 1653-64.

Sherman, Ann E., and Sheridan Titman. 2002. Building the IPO order book: Underpricing and participation limits with costly information. Journal of Financial Economics 65: 3-29. [CrossRef]

Schreiner, Andreas, and Klaus Spremann. 2007. Multiples and Their Valuation Accuracy in European Equity Markets. Available online: http:/ / ssrn.com/abstract=957352 (accessed on 7 April 2013).

White, Halbert. 1980. A heteroscedastic-consistent covariance matrix estimator and a direct test of heteroscedasticity. Econometrica 48: 817-38. [CrossRef]

Yoon, Jun. 2015. Multiples Valuation and Abnormal Returns. Honors dissertation, Duke University, Durham, NC, USA, April 17.

(C) 2018 by the authors. Licensee MDPI, Basel, Switzerland. This article is an open access article distributed under the terms and conditions of the Creative Commons Attribution (CC BY) license (http:/ / creativecommons.org/licenses/by/4.0/). 